\title{
Ssciendo
}

Ethics \& Bioethics (in Central Europe), 2019, 9 (3-4), 139-147

DOI:10.2478/ebce-2019-0023

\section{Hugolín Gavlovič on moral education: Enlightenment ideas in baroque literature?}

\author{
Katarína Komenská ${ }^{1}$
}

\begin{abstract}
The work of Hugolín Gavlovič belongs is part of the most influential literary and didactic heritage of $18^{\text {th }}$ century literature in the region of contemporary Slovakia. Even though Gavlovič was not a systematic moral philosopher, the role and importance of ethics in his literary work is significant. He contributed greatly to the debate on moral education, which was (in the context of that time) linked to the fulfilment of God's will and to the accomplishment of a good life. In his extensive poetic work Valaská škola mravúv stodola [Shepherd's school of morals], the author not only formulated moral norms but, inspired by classical Greek philosophy, he also defined them in the wider ethical context of virtue, morals, and human nature. In this study, the historical context of his work, marked by the literary and cultural transition to the Enlightenment era, will be presented, concepts related to the understanding of good life (as a goal of moral education) will be identified, and the possibility for further philosophical and ethical analysis of Gavlovič's work will be offered (through a reflexion of Aristotle's thoughts referred to in Valaská škola). Overall, the paper offers an original point of view on how to interpret the thoughts of Hugolín Gavlovič from the perspective of ethics. This has been, despite the impact of his work, rather omitted.
\end{abstract}

Keywords: Hugolín Gavlovič; ethics; virtue; morals; moral education

\section{Introduction}

No author can be read and fully understood outside of the historical, social, and political contexts of his/her time. These contexts directly influence (either in a critical or affirmative way) the author's thinking and perceiving the world. This can be also observed in the work of Hugolín Gavlovič, whose literary work reflected on the transition from the philosophical and cultural tradition of baroque to the Enlightenment period in Slovakia. In general, the transition of thinking in the work of Slovak authors of the $17^{\text {th }}$ and $18^{\text {th }}$ century has only recently become a focus of literary-historical analysis and research (Žemberová, 2017, p. 244) and it has become an inspirational source for further analysis and comparison. Especially interesting is to seek for original reflections of new philosophical and ethical thoughts in the literature of that time, which is also the main goal of the present study.

As mentioned above, an example of this cultural transition is Hugolín Gavlovič who, from the perspective of literary analysis, is a representative of religious and baroque literature, but in terms of wider cultural, philosophical-ethical, social, and aesthetic value, his work can be regarded as a form of pre-Enlightenment thinking (Kuchár, 1988; Habovštiaková, 1970). This is also a reason why, even in his own time, Hugolín Gavlovič was considered to be a "stranger" (Gáfriková, 2002, p. 55). It is difficult to read his literary pieces as typical representations of that era's literature, which might have been caused by his life as a monk outside of the literary circles of the cultural centers of Austria-Hungary. His thoughts need to be therefore analyzed in wider cultural and historical contexts

\footnotetext{
${ }^{1}$ University of Prešov, Institute of ethics and bioethics, Prešov (Slovakia); katarina.komenska@unipo.sk
} 
Hungary, as a part of the Austria-Hungary monarchy, did not significantly contribute to the cultural, political, or philosophical-theological transformation of Western Europe. ${ }^{2}$ Modern thoughts (such as the spread of rationalism or critical attitudes towards religious dogmatism) were adopted rather slowly in the region. Nevertheless, some reflections on Enlightenment ideas can be observed. The dynamic historical development of $18^{\text {th }}$ century Hungary appeared at several levels of social and political life. For the purpose of an ethical analysis of Hugolín Gavlovič's work, attention will be drawn to three of its important aspects, which can also be recognized as important aspects of short-lasting Enlightenment period and philosophy in the region of Austria-Hungary.

Firstly, the feudal society still prevailed in the whole region of Central and Eastern Europe. ${ }^{3}$ Because of that, the social, economic, as well as moral authority of land-owners, the aristocracy, and/or representatives of the Church, could be perceived. Only rarely were there any confrontations or critical attitudes towards the existing status of the societal order or any requirement for equalization of the moral status of all members of the community. Even as late as the 1880s and despite increasing social criticism in the literature and culture of the region, the author Jozef Ignác Bajza, whose work is considered to be the peak of Enlightenment ideas in the region, still declared a great respect for authority. This respect was dedicated to the governmental and state authority, Joseph II., who he considered as the leader of Enlightenment absolutism in Austria-Hungary. Despite the desire for complete modernization of the state, its reformation and secularization (Kollárová, 2013), the Church was not excluded from the decisions made in implementing, or later reducing, these reforms and laws. In such cultural contexts, the influence of the Catholic Church and its ideology of natural order persisted. Men accepted their status and roles in the society as predetermined and as the destiny of their everyday lives. Despite the tendency of the intellectual elite to support the idea of equality and freedom, peasants remained conservative and obedient to feudal land-owners and their oppression (Kollárová, 2013).

The second aspect to be emphasized is the idea of education and humanization. Literary works of the time started to be concerned not only with the enlightenment of scholars but with the education of the so-called plebeian community, too (Bilasová, 2010; Kalajtzidis, 2010; Šolcová, 2017). Education started to be seen as a general, universal need of all people, even common people (peasants, farmers, shepherds). A new form of education started to be promoted, especially through the system of compulsory schooling ${ }^{4}$ which, in some way, became secularized. In the middle of the $18^{\text {th }}$ century, this had significantly influenced the number of educated members in society, for example writers, preachers, doctors, invertors, as well as folk healers, etc. (Bilasová, 2010). In literature, it led to the promotion of a secularized form of education, to declare necessary access to moral and practical education for the public, to open the monasteries, libraries, schools to everyone, to critically evaluate moral education based on the Catholic Church and its moralized norms. This was, for example, humorously, satirically, and socio-critically described and explained in the Jozef Ignác Bajza’ works (Bajza, 2007, 2 ${ }^{\text {nd }}$ part; Števček, 1988).

\footnotetext{
${ }^{2}$ There were even significant cultural differences between the Austrian and the Hungarian part of the monarchy. The development of the Czech part of the monarchy was much more vivid in comparison to the region of Slovakia (Šolcová, 2018, pp. 33-40).

${ }^{3}$ During the regime of Maria Theresia and, later on, of Joseph II., a slow liberation of feudal structures took place. The main goal was to abolish serfdom (Kalajtzidis, 2010). In Hungary, this happened in 1785. It was preceded by urban regulation (Theresian Urbarium, 1767) and the Patent of Toleration (1781). These economic, political and social changes were not primarily motivated by ideas of humanity and dignity. They were rather pre-conditioned by military and economic needs to revitalize the competitiveness and effectiveness of Hungary (Kalajtzidis, 2010, p. 13).

${ }^{4}$ Legally introduced by Maria Theresia in 1774.
} 
Thirdly, the overall interest in ethics as a philosophical discipline, which spread local as well as pan-European thinking during that period, had a direct historical impact on many authors, including Gavlovič. The vivid development of ethical thinking was especially significant in the $17^{\text {th }}$ century and lasted through to the first half of the $18^{\text {th }}$ century (Oravcová, 1989, p. 40). Many authors of that time followed similar paths (e.g. Jozef Ignác Bajza who literally implemented the thoughts of classical Greek philosophy and/or of French prosaic work (Žemberová, 2016, pp. 47-52).

To sum up, these three significant aspects of $18^{\text {th }}$ century Hungarian cultural life were reflected in the promotion of Enlightenment thoughts through the literary work of several authors, such as Ján Baltazár Magin or Jozef Ignác Bajza. Despite the fact that the Enlightenment did not last in the region very long, there are authors who were significantly influenced by it. One of the first historical figures, whose work was marked by the above mentioned ideas, was Hugolín Gavlovič. He can be considered to be one of the pillars of the transition between baroque and Enlightenment thinking, in other words a pioneer of the Enlightenment in the then Slovak part of the AustroHungarian Empire.

\section{Moral education in the work of Hugolín Gavlovič}

Hugolín Gavlovič responded to these impulses in full complexity, especially by dedicating his work to ordinary members of the Christian community (Gafríkova, 2004, p. 9). It is for them, without any unnecessary religious formalism or moralizations, he prepared simple "school exercises" of a good life. He was one of the most important authors of his time who focused on the issues of moral education and humanization in society. Distinctively, his effort was not to moralize, but rather to formulate the main goal of education in its connection to the moral development of man. He believed that a good life is to be lived in accordance with God's commandments, but only personal moral development and responsibility can help people carry out their Christian faith in everyday life. As mentioned above, these efforts are clearly reflected in his most extensive and most important literary work, Valaská škola mravúv stodola. ${ }^{5,6} \mathrm{In}$ it, he worked with two main motives. Firstly, there is his interest in ethics as one of the most dynamically evolving philosophical disciplines of that period (Gáfriková, 2002). Secondly, the humor and playfulness in presenting his moral thoughts created an original didactic style. It helped him overcome the limits of catechism in moral education and prepare simple guidelines for people to live moral lives (Kákošová, 2002; Šmatlák, 1997, p. 280).

The re-occurring theme in Gavlovič's work is man as an object of education. This man is often presented as an ordinary, common person (usually a shepherd) who, despite a limited or even nonexistent education, can become a moral person able to recognize his/her role in the world (both with regard to society and to God). A sort of liberation process of the villeins can be perceived in

\footnotetext{
${ }^{5}$ The name of this book might be freely translated as Shepherd's School of Morals, which might help us reflect not only on the pastoral setting, the main target of Gavlovič's education (of ordinary, uneducated people), as well as the goal of this education (morals, virtues). Similarly to this book, didactic exercises for moral development and solving ethical questions are evident in all his works, e.g. Škola krestanská, s veršami zvázaná [Christian school bound in verse] (1758) (recently reprinted: Gavlovič, 2012) or 500 naučeni o dobrých mravoch [500 lessons on good morals] (1782).

${ }^{6}$ For the purpose of this article, I do not find it elementary to focus on the structure of the book (prelude, 22 notes, and epilogue). Still, it is of some interest to mention a specific genealogy depicted in all of the notes, which reflects on the biblical stories starting from the Old Testament leading to the New Testament. The baroque and Renaissance influences of authors' literary form, concepts, depicts these stories in parallels and inner links with realities of his own time, which allows him to offer his readers his own didactic and reflexive messages in "various forms of bitter, spiritual and aphoristic declarations" (Gáfriková, 2002, p. 56). For more details, I recommend an article by Gizela Gáfriková, Literárne dielo Hugolína Gavloviča [Literary works of Hugolín Gavlovič] (2002).
} 
these verses. ${ }^{7}$ Gavlovič claimed that every person has a value in himself; a value which should be fully respected. To guarantee this basic respect, Gavlovič formulated in his stories moral obligations of all members of the community to behave morally and virtuously towards others (Lalíková, 1990), including the aristocracy and feudal lords towards their villeins. For example, verses such as "Useless is he who feasts so often that his villeins struggle to provide for his

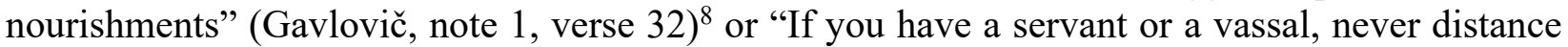
your gracious heart from him" (Gavlovič, note 3 , verse 46 ) ${ }^{9}, 10$ express the reciprocal and morally obligatory relationship among different social groups.

Another significant motive of Gavlovič's work is his understanding of education. He rejected a narrow definition of school as a means of formal education and knowledge. He declared that pure facts would never allow a man to fully comprehend the world. Only a man with God and goodness in his/her heart can find a place in this world and can fulfil his/her life goals. "Useless is a school, where there is nothing but disputes, as educated is the one, who has god-like love in his heart" and "If a man disputes in all his power, he will not recognize what was at the beginning and what will be at the end" (Gavlovič, note 7, verse 1). ${ }^{11}$ Despite many practical guidelines offered in his work, his primary focus in education is paid to the development of virtues and morals, and to the understanding of God's commandments in one's life. Therefore, Gavlovič's primary attention is dedicated to questions of moral education. For him, more important than moralization and formulation of individual norms of ethics, was the delimitation of the main goals of education and how they are linked to morals, virtues, and policia (rules, external norms). Inspired by classical Greek philosophy, Gavlovič understood morals and morality as arising from virtues of men. Morality of the person is not something that is in one's nature, but something s/he has to build and develop throughout life. It is a significant shift from the Mediaeval formalistic understanding of ethics based on the acceptance of dogmas and Christian ideology. In the prelude to Valaská škola, entitled $O$ dobrých mravoch [On good morals], he carefully presented his ideas. Good life (as a goal of moral education) is based on two pillars: morals and virtues. "Good morals are always close to virtues, if they are distant from virtues, they are usually not stable" and "The first pillar is good morals, the second pillar is virtues; God's Commandments stand between them as in a fortress". ${ }^{2}$ These are interlinked and mutually influence each other. "If good morals fail, and virtues, too, then slowly God's Commandments will fall apart, too". ${ }^{13}$ Besides helping man to lead a good life, they also promote God's Commandments.

If we talk about these two pillars of good life, virtues are the initiators. This is not due to any chronology or hierarchy, as virtues and morals are, in the end, of the same importance for leading a good life. What is significantly different is that virtues are something internal and hidden from the external world. Rather, they take the form of man's inner willingness to do good; a form of

\footnotetext{
${ }^{7}$ This process can be considered more like a moral liberation of man, not a legal one. During the time when Gavlovič wrote his works, the legal abolition of serfdom was not yet a political question. But from the perspective of ethics and morality, we can perceive the focus on individualistic morality and ethos in his verses.

8 „Marný je ten, ktorý často privykel hodovat', na stúl jeho I poddaní nestačá pracovat”' (Gavlovič, note 1, verse 32).

9 "Jak máś tvého služebníka, aneb poddaného, nikdy srdca láskavého nevzdaluj od neho" (Gavlovič, note 3, verse 46).

${ }^{10}$ Another, and maybe even more complex, formulation of moral obligation of feudals and the aristocracy towards their vassals is presented in Gavlovič's note 5, verse 27. He encouraged feudals not only to be generous, but also to be patient and paternalistic, as fathers towards their children, acting always with grace (Gavlovič, note 5, verse 27).

11 "Marná škola, kde nic jiné krem dišputování, ten učený, kdo má v srdci boské milování" and "Nech se človek dišputuje ze všej svojej moci, nezví, čo bylo spočátku, čo bude pri konci” (Gavlovič, note 7, verse 1).

12 „Dobré mravy vždy s cnost'ami susedstvo mívajú, jak sú od cností vzdálené, stálé nebývajú” a "První múr sú dobré mravy, druhý múr sú cnosti, príkaz boží medzi nimi stojí jak v pevnosti” (Gavlovič, O dobrých mravoch).

13 "Jestli spadnú dobré mravy, a i cnosti spolu, potem pomaly i príkaz boží jide dolu" (Gavlovič, O dobrých mravoch).
} 
consciousness. The most important virtues praising God's will are justice, moderation, strength in faith, hope, and love. ${ }^{14}$ The other virtues linked to life in society are virtues of bravery, respect, and solidarity. ${ }^{15,16}$

Virtues, because of their inner character, are not enough to reach the moral goal of man's life. Gavlovič explained that it is not enough to think about good, but also to focus on acting accordingly: "It is a good thing to recognize good things, but better is if you can fulfill it in action" (Gavlovič, Pripomínání o trojnásobnej policii...). ${ }^{17}$ Virtuous people should not focus only on their inner, spiritual life, but they have to learn how to act morally, too. This is what Gavlovič understood to be morals: the external outcomes of one's virtues. Morals can be supported in life by education, habits, and conventions.

Good morals are adornments of one's life; the external beauty that can be observed by others. But virtues are perceived more as scents accompanying the good action, odours which are often hidden to others; others except God. Because of this, virtues and morals have to be closely interlinked and support each other. If one pillar fails, the other fails soon after and God's will cannot be promoted in a person's life (Gavlovič, O dobrých mravoch). If God's Commandments are to be protected purely by virtues, without their embodiments in the form of morals (as external manifestations of goodness and God's Commandments), man and the whole society will not live good lives. Both these pillars of life have to be in harmony. ${ }^{18}$

A person has to have both good consciousness and good morals because only if the goodness spreads from one's character can it be performed and manifested in everyday actions and in society. "What can be of benefit to the neighbor or to himself, he aspires to act on in a good manner. What is safe, praiseworthy, and free to do, to this he inclines; the lust for bad there is none in his heart. What he judges to be good according to his consciousness, he conducts" (Gavlovič, Katoliko-politik má dobré svedomí i dobré mravy). ${ }^{20,21}$

To develop and support the strength of both pillars of good life, education is necessary. Gavlovič avoided the dogmatism of Christianity and its moralizations. It is more important, as pronounced in his work, to focus on consciousness and virtues in education, which can help people follow God's will and his grace. This is a much better means of leading a good life, as policia formulated by the society might mislead us, might be egoistic and of interest to others but God's.

\footnotetext{
${ }^{14}$ Policia krest'anská, táto cíli k chvále boskej [Christian policia aiming to God's glory].

${ }^{15}$ Policia mestská, neb civilis. Tá cílí k pokoji, i k užitku bližního [Citizen policia, or civilis. Which aims to the peace and benefit of others].

${ }^{16}$ Surprisingly, Gavlovič does not consider freedom to be a virtue as it can lead man to situations when he consciously harms, by act or by word, other members of society (Gavlovič, Ego sum Pastor bonus).

17 “Dobrá vec jest dobré veci vedet’ i mluviti, ale lepšá, když i skutkem múžeš jich plniti” (Gavlovič, Pripomínání o trojnásobnej policii...).

18 Otherwise, a person can easily incline to become a person stoico-politic or a person sofistico-politic. In such lives, the person either follows strictly policia (norms) without their critical reevaluation by the consciousness or virtues (Lalíková, 1990, p. 372) or too self-centred and egoistic, with poor consciousness and weak policia in the social morality.

${ }^{19}$ A member of which is the person, too, and therefore has his/her role and moral and social obligation.

${ }^{20}$ Čo múze byt' užitečné bližnímu neb sobe, to se činit’ usiluje pri dobrém spúsobe. Co bezpečné, chválitebné, slobodné k činení, k tomu má chut'; chuti k zlému v srdci jeho neni. Co súdí podle svedomí dobrého, to činí” (Gavlovič, Katolikopolitik má dobré svedomí i dobré mravy).

${ }^{21}$ Catholica-politic has good consciousness and good morals.
} 


\section{The philosophical and ethical foundation of Hugolín Gavlovič}

Despite Gavlovič's interest in ethical issues, he was never a systematic philosopher who wanted to offer his readers a deeper, ethical and philosophical conceptualization of moral education and good life. His work was rather didactic. The philosophical and ethical aspects of his thoughts are rather indirectly implied with references to "moral teachers" introduced by their quotations in the prelude to his Valaská skola mravúv stodola, entitled Zmysly učitelúv o dobrých mravoch [Teachers' thoughts on good morals]. In the prelude, Gavlovič quotes Seneca, Plato, Socrates, Ovidius, Cicero, Pythagoras, Erasmus of Rotterdam, Aurelius Augustine, Aristotle, and many others. ${ }^{22}$ Following the ideas of these teachers, his work emphasized virtues and the moral development of one's character. $^{23}$

To analyze deeper the ethical basis of moral education in Hugolín Gavlovič's thoughts, let us try to interpret his literary work by complementing it with the ethical concept of good life and virtue in the work of Aristotle. ${ }^{24}$ According to Aristotle, man's life mission is happiness. Eudemonia is the highest goal as man tries to reach it for itself and not for anything else (Aristotle, EN 1095a). Aristotle also explained that man can fulfil such a mission only in actions. Those must be based on rational choices (the activity of the soul) using man's rational part of the soul (reason). "Now if the function of man is the activity of the soul which follows or implies reason [...] human good turns out to be an activity of the soul exhibiting virtue" (Aristotle, EN 1098a). This ability of man is then called moral virtue (éthiké). Consequently, only the implementation of virtue allows the person become a good person who leads a good life. In Gavlovič, the two pillars of good life (virtues and morals) reflect on the same connection between virtues and actions, between the soul's activity and real, external activity.

Aristotle did not ignore the fact that external factors have impact on the ability of man to reach happiness. He understood that the motives and moral actions of man do not have to be enough to lead a good life. "[I]t needs external goods as well; for it is impossible, or not easy, to do noble acts without the proper equipment. In many actions we use friends and riches and political power as instruments; and there are some things the lack of which takes the luster from happiness - good birth, goodly children, beauty; for the man who is very ugly in appearance or ill-born or solitary and childless is not very likely to be happy and perhaps a man would be still less likely if he had thoroughly bad children or friends or had lost good children or friends by death. As we said, then, happiness seems to need this sort of prosperity in addition; for which reason some identify happiness with good fortune, though others identify it with virtue" (Aristotle, EN 1099a; 1099b).

In accordance with this, it can be assumed that Hugolín Gavlovič also reflected on the issue of external factors, external goods while debating on the social status and role of man and the moral obligations of those happier in this matter to be just and virtuous to those less lucky in economic and social status. As depicted in the above mentioned verses (Gavlovič, note 1, verse 31; note 3, verse 46; note 5, verse 27), the aspect of social system built around God's commandments was a dominant issue in his work. This confirms what Gáfriková named as an idea for the overall formation of Christian society (Gáfriková, 2004, p. 9). Another example is note 17, verse 27, in which Gavlovič not only depicted common injustice and inequity in social and the economic

\footnotetext{
${ }^{22}$ Later works of Hugolín Gavlovič are dedicated to deeper ethical analysis of interpersonal relationships and to cultivation of man (e.g. Škola krestanská, s veršami zvázaná [Christian school, bound in verse] (1758) with its more precise analysis of the school of virtues) or to an inclination to the Erasmus tradition in his later work 500 naučeni o dobrých mravoch [500 lessons on good morals] (1782) (Gáfriková, 2004, p. 24).

${ }^{23}$ More on the philosophical scope of Hugolín Gavlovič in Oravcová (1989) and Šmatlák (1997, pp. 274-280).

${ }^{24}$ A similar inspiration by Aristotle can be perceived in the works of J. A. Comenius and his interpretation of moral virtues (Šolcová, 2017; Misseri, 2017).
} 
situations of persons to which they are born to, but, similarly to Aristotle, he also emphasized the link between external factors and social status and situation in life as such. Seeking for parallels between Gavlovič's understanding of social order and the relationship between ethics and politics in Aristotle's work, ${ }^{25}$ becomes a relevant topic for further analysis. A good person is not only a good, virtuous person, but also a virtuous member of the society, a good citizen (Leško, 2004, pp. 118-122). Virtues help people live among other people and in relationships with others (Volek, 2011, p. 13). ${ }^{26}$

Another visible Aristotelian influence on Hugolín Gavlovič can be perceived in the above mentioned prelude to Valaská škola, where he directly referred to Aristotle by quoting that virtues do not spread from one's nature but from habits (ethos) and that if man gets used to good morals, you will appreciate and grace them. In Aristotle, further insight can be found: "moral virtues come about as a result of habit [...] from this it is also plain that none of the moral virtues arises in us by nature; for nothing that exists by nature can form a habit contrary to its nature" (Aristotle, EN 1103a). For Gavlovič, the appeal for education for good morals and recognizing God's commandments becomes elementary to acquire and develop one's virtue of character. ${ }^{27}$ In other words, on one hand, man's virtues would never develop without good actions and morals, but, on the other hand, good morals must be supported by one's natural ability to act. Gavlovič agreed with Aristotle that there is some predisposition and ability in man to incline to good life, to eudemonia, but it must be promoted by habits and morals, otherwise it will be stunted. Although he understands the necessity for continuous development of the conscience, virtues and morals of man, in his work (dedicated to laic Christians) he emphasized mostly the development of morals obtained by habits and repetition in his goals of moral education. This does not go in opposition to Aristotle's conclusions, it simply refers to the specific aim and target of his literary and didactic work.

\section{Conclusion}

Hugolín Gavlovič emphasized education as a means for every person to lead a good life. Therefore, he linked education to moral education, more concretely to the gradual development of virtues and morals in an individual person. Several cultural, historical, and philosophical influences can be detected in his work. Firstly, the influence of a strong Christian tradition in which good life is understood as life that follows and fulfils God's will. Secondly, the influence of Enlightenment thinking, for example, his understanding of the value of human life as something that needs to be fully and unconditionally respected and recognized. Gavlovič claimed that every person has their value and role in the world. Also, he rejected the dogmatism of the Christian Church and emphasized the role of consciousness of the person and his/her virtues. Only through them, he concluded, can man follow God's wishes. Virtues are therefore a more important tool for the process of moral decision making and actions than policies formulated by society. Last but not least, there are strong influences of classical philosophers and ethicists, to whom Hugolín Gavlovič directly referred in his work, e.g. Erasmus of Rotterdam, Seneca, Cicero, and many others. He was widely interested in ethical discourse, which not only formed his thematic interest, but also the

\footnotetext{
${ }^{25}$ Aristotle delimitates that the goal of political and social community must be the good life of its members (Šuvalíková, 2008, p. 336).

${ }^{26}$ For such interpersonal cooperation, the virtue of justice is also important; the virtue necessary for social and political cooperation and cohabitation. More on the analysis of justice as an ethical virtue in the article by Ján Kalajtzidis (2017). ${ }^{27}$ The link between both of these pillars of good life is reflected in several notes in Gavlovič's work, for example Telu mravy, cnosti duši zhromáždzovat' vždycky sluši [Body for morals, virtues for the soul, gathering them always satisfies a man] (Gavlovič, note 5, verse 12) or Nadobudeš pekné mravy, jestli budeš v cnostech zdravý [You obtain fair morals if your virtues are healthy] (Gavlovič, note 6, verse 21).
} 
form and structure of his arguments. In the final part of the present study, several examples from Aristotle's work were shown as referential points for further philosophical and ethical analysis of Gavlovič's moral philosophy and thinking.

Despite his undebatable literary talent and importance (both aesthetic and linguistic) and wide interest in the thoughts of humanization, education, and moral development, his heritage as an Enlightenment thinker can be considered as a rather sporadic and rare input into this cultural transition. Working in the rather isolated condition of monasteries, surrounded by other members of the Church, and dedicating his sermons and literary work to ordinary people, he did not directly influence the culture and literature of that time and the literary elite of Hungarian society. He stayed focused on his own mission; to create a better, more moral and enlightened world and society and therefore, we should read his work as such.

\section{Acknowledgement}

This article was supported by the project "International mobilities for research activities of the University of Hradec Králové", CZ.02.2.69/0.0/0.0/16_027/0008487 and by the KEGA project "Elearning module of History of ethical thinking in Slovakia II. ( $2^{\text {nd }}$ half of $18^{\text {th }}$ century -1918$)$ ".

\section{References}

ARISTOTLE (2009): The Nicomachean ethics. Oxford: Oxford University Press.

BAJZA. J. I. (2007): Príhody a skúsenosti mládenca Reného (II. Diel) [Stories and experiences of the youth René (II. Part)]. Bratislava: Zlatý fond denníka SME.

BILASOVÁ, V. (2010): Metamorfózy étosu v 18. storočí [Metamorphosis of ethos in the $18^{\text {th }}$ Century]. In: V. Gluchman (ed.): Etika na Slovensku (a v Európe) v 17. a 18. storočí [Ethics in Slovakia (and Europe) in the $17^{\text {th }}-18^{\text {th }}$ Century]. Prešov: FF PU, pp. 17-26.

GÁFRIKOVÁ, G. (2004): Nad literárnym dielom slovenského „podivína 18. storočia“ [On the literary work of Slovak " $18^{\text {th }}$ century stranger"]. In: H. Gavlovič: O dobrých mravoch [On good morals]. Bratislava: Slovenský Tatran, pp. 5-26.

GÁFRIKOVÁ, G. (2002): Literárne dielo Hugolína Gavloviča [Literary work of Hugolín Gavlovič]. In: Studia Academica Slovaca. Prednášky XXXVII. letnej školy slovenského jazyka a kultúry [Studia Academica Slovaca: Lectures from the XXXVII Summer school on Slovak Language and Culture], 31(1), pp. 55-69.

GAVLOVIČ, H. (2012): Škola krest’anská [Christian school]. Bratislava: Kalligram. GAVLOVIČ, H. (1988): Hugolín Gavlovič's Valaská škola [Hugolín Gavlovič's shepherd's school, ed. G. J. Sabo. Columbus, OH: Slavica.

HABOVŠTIAKOVÁ, K. (1970): Jazyk Hugolína Gavloviča [Language of Hugolín Gavlovič]. In: Slovenská reč, 35(1), pp. 79-87.

KÁKOŠOVÁ, Z. (2002): Slovenská literatúra pred rokom 1780 (žánrovo-tematické premeny literatúry od stredoveku po barok) [Slovak Literature before 1780: The Shifts in Genre and Themes from the Middle Ages to Baroque]. In: Studia Academica Slovaca. Prednášky XXXVII. letnej školy slovenského jazyka a kultúry [Studia Academica Slovaca: Lectures from the XXXVII Summer school on Slovak Language and Culture], 31(1), pp. 100-114.

KALAJTZIDIS, J. (2010): Eticko-filozofická reflexia hospodársko-spoločenských premien 18. storočia na území dnešného Slovenska [Ethical and philosophical reflections of economic and social changers during the $18^{\text {th }}$ century in the contemporary area of Slovakia]. In: V. Gluchman (ed.): Etika na Slovensku (a v Európe) v 17. a 18. storoči [Ethics in Slovakia (and Europe) in the $17^{\text {th }}-18^{\text {th }}$ Century]. Prešov: FF PU, pp. 9-16. 
KALAJTZIDIS, J. (2017): Reflexia vplyvu Aristotelovho chápania problému spravodlivosti $\mathrm{V}$ našom kultúrnom okruhu [Reflections of Aristotle's influence on the problem of justice in our cultural heritage]. In: Konštantínove listy, 10(1), pp. 110-120.

KOLLÁROVÁ, I. (2013): Slobodný vydavatel', mysliaci čitatel' [Free publisher, thoughtful reader]. Budmerice: Rak.

KUCHAR, R. (1988): Vedecká konferencia o diele Hugolína Gavloviča [The scientific conference on Hugolín Gavlovič]. In: Slovenská reč, 53(1), pp. 55-57.

LALÍKOVÁ, T. (1990): Hugolín Gavlovič v dejinách slovenskej kultúry [Hugolín Gavlovič in the history of Slovak culture]. In: Slovenská reč, 55(6), pp. 371-374.

LEŠKO, V. (2004): Dejiny filozofie I [History of philosophy, vol. I]. Prešov: FF PU.

MISSERI, L. E. (2017): Comenius' ethics: from the heart to the world. In: Ethics \& Bioethics (in Central Europe), 7(1-2), pp. 13-23.

ORAVCOVÁ, M. (1989): Filozofický kontext Gavlovičovej tvorby [Philosophical context of Gavlovič’s work]. In: I. Sedlák (ed.): Hugolín Gavlovič v dejinách slovenskej kultúry [Hugolín Gavlovič in the history of Slovak culture]. Martin: Matica Slovenská, pp. 38-47.

ŠMATLÁK, S. (1997): Dejiny slovenskej literatúry I. (9.-18. storočie) [The history of Slovak Literature $\left(9^{\text {th }}-18^{\text {th }}\right.$ Century)]. Bratislava: Národné literárne centrum.

ŠOLCOVÁ, K. (2017): Moral virtues in J.A. Comenius' Mundus Moralis. In: Ethics \& Bioethics (in Central Europe), 7(3-4), pp. 119-126.

ŠOLCOVÁ, K. (2018): Jessenius' contribution to social ethics in 17th century Central Europe. In: Ethics \& Bioethics (in Central Europe), 8(1-2), pp. 33-40.

ŠTEVČEK, J. (1988): Fikcia a pravda Bajzovho románu [Fiction and truth of Bajza's novel]. In: Slovenská literatúra, 35(4), pp. 344-358.

ŠUVALÍKOVÁ, B. (2008): Integrita a dobrý život [Integrity and good life]. In: Filozofia, 63(4), pp. 336-343.

VOLEK, P. (2011): Vplyv aristotelizmu pri vysvetl'ovaní konania u Tomáša Akvinského a Rajmunda Lulla [The influence of Aristotelian thoughts on the interpretation of actions in Thomas Aquinas and Rajmund Lulla]. In: Filozofia, 66(1), pp. 11-23.

ŽEMBEROVÁ, V. (2016): Z výskumu kultúrnych a literárnych dejín národnej identity [Cultural and literary-historical research on the national identity]. In: Cultorologica Slovaca, 1(1), pp. 4752.

ŽEMBEROVÁ, V. (2017): Etika v minulosti, minulost' v etike v literárnej histórii a v umeleckom texte [The ethics of the past, past in the Ethics, history of literature, and in the artistic text]. In: V. Gluchman (ed.): Etika na Slovensku (a v Európe) v 17. a 18. storoči [Ethics in Slovakia (and Europe) in the $17^{\text {th }}-18^{\text {th }}$ Century]. Prešov: FF PU, pp. 237-250. 